glacial observer may visit the locality some day, and give us the benefit of his opinion upon it. In the meantime, as Mr. Pengelly, in his letter in your last number, agrees in the correctness of my description of the facts, perhaps he will favour us with his ideas as to their origin, for I certainly have never seen anything like them except on a so-called glaciated surface.-Yours truly,

Dublin, Dec. 4, 1866.

J. Веete Jukrag.

\title{
DR. FRAAS ON PRE-HISTORIC SETTLEMENTS.
}

To the Editor of the Geological Magazine.

Sir,-In your impression of this month (page 550), Dr. Fraas concludes an interesting article on Pre-historic Settlements with two remarks, thus: "And, secondly, that the discovery at Schussenried indicates a totally different climate, such as now begins at 70 degrees of north latitude." But he gives a fact which fully contradicts this theory. The remains of horses were found at Schussenried. "In one case the skull is still nearly perfect, and it belonged to a species with a large head; while certain bones of the extremities indicate a strong, bony, and powerful animal. The brain cavity has been opened, the vertebræ had been split, and the bones containing marrow had been broken in pieces, so that there can be no doubt of horse-flesh having been one of the table delicacies of the ancient Swabians." Are there wild horses at the North Cape now? or in Nova Zembla? or at: the Samoyede Promontory?

I have the honour to be, Sir, your obedient servant, George Gremwood, Colonel.

Brook wood Park, Alresforid, December $7 t h, \mathbf{1 8 6 6 .}$

\section{THE DEVONIAN ROCKS OF NORTH DEVON.}

\section{To the Editor of the Geological Magazine.}

Drar SrR,-I wish I had power at present to enter the lists op the new issue raised by Professor Jukes as to the integrity of the Devonian system. It seems so odd to try to explain away a series of rocks which must have some place, and are distinguished, as all know, by a peculiar set of fossils. Though the Devonian has not many striking peculiar types of shells, it has some quite distinct, while the mass of its species are undoubtedly peculiar, and neither Silurian nor Carboniferous. And it is 10,000 feet thick!

Meanwhile. till 1 have more opportunity, let me just keep your younger readers in possession of the facts that in North Devon, proceeding southwards from Linton and the N. Foreland to the. Culm-measures, there are the following distinct series; which Professor Jukes rather summarily groups into Coal, Carboniferous-slate, and Old Red. I know "a rose by any other name will smell as sweet," but I prefer the well-known names:-

1. Slates and sundstones of Linton and the North Foreland (Lower Devonian).

2. Grey slates and limestones of Combe Martin and Ilfracombe (Middle Devenian). 